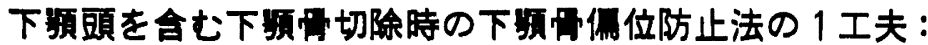

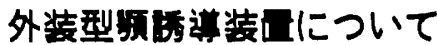

\author{
裀时㡲志
}

\section{A new method to align and stabilize the remaining mandibular segment for mandibulectomy including the mandibular condyle: An external pin fixation appliance with the devices guiding the mandibular movement}

\author{
Hiroshi FukudA
}

\begin{abstract}
The method to align and stabilize the remaining mandibular segment for the mandibulectomized patient including the mandibular condyle was reported in this article. The method used is modification of the external pin fixation. The difference between the ordinary method and the author's method is that the devices guiding the mandibular movement are attached to the ordinary external pin fixation appliance.

The merits are as follows.

1. The patient can open his mouth guided by the devices attached to the ordinary external pin fixation appliance without changing the position of the remaining mandibular segment.

2. The patient can eat orally in the early postoperative period.

3. Postoperative care becomes easier because observation of the oral cavity is easy.
\end{abstract}

Key words: mandibulectomy, external pin fixation, devices guiding the mandibular movement

緒

春

下䫑骨切除後の久損に対しては自家骨による即時再建 が口腔機能保持の点から望ましい.しかし即時再建の成 功率が低いこともあり ${ }^{1)}$, 一時的に下顥の偏位を防止し, 二次的に下額骨の再建を行らことも多い．そのさいには 二次的再建時の上下顎の位直関係の回復を容易にするた め, 下頻骨切除時に下顥の偏位を防止する事が望まし くその目的で従来より種々の工夫がなされてきてい る.下額頭が保存されている場合には骨釘等により開口 制限を行らことなく，下影骨の上影骨に対する位直関係 を良好に保つことは可能である。しかし下顥頭を含む切 除術が行われた場合で，かつ患者が義齿を装着している

\section{筑波大学臨床医学系口腔科}

(主任: 根本一男数授)

Department of Stomatology, Institute of Clinical Medicine, University of Tsukuba (Chief: Prof. Kazuo Nemoto)

受付日：昭和59年11月 5 日
場合には，崡に維持を求める滑面板，斜面板の適用は困 難で，買運動を制限し残存下䫛骨の位置を維持する方法 かとられている。 しかしなから開口制限による心理的影 部も無視できなく2，顎運動の可能な下䫛の偏位防止法 が望ましいと考える.

今回, 著者は下顥頭を含む切除術が行われた場合で， 歯に稚持を求めることなく残存下罘骨の位置を維持しつ

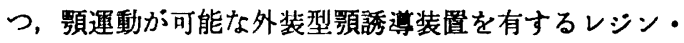
ハーを考案し，良好な結果を得ているので術式を報告 し，代表例を紹介する.

術式

現在までに2つの術式を施行してきている，その違い は外装型䫏誘導装置の維持法にあって, 第 1 法は煩骨弓 に維持を求めるすのであり(以下，第 1 法), 第 2 法は 煩骨に維持を求めるものである(以下，第 2 法). しか し基本的な術式は同じであるので，まず基本術式につい て報告し，ついで外装型䫁誘導装置の維持法について述 ベることにする. 


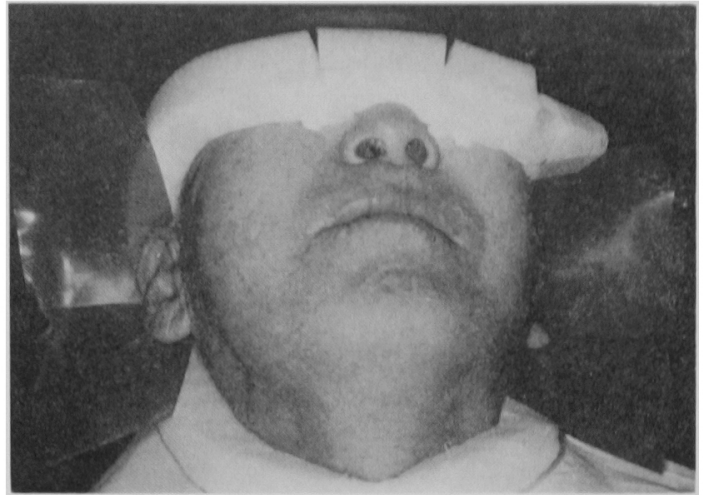

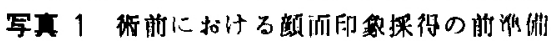

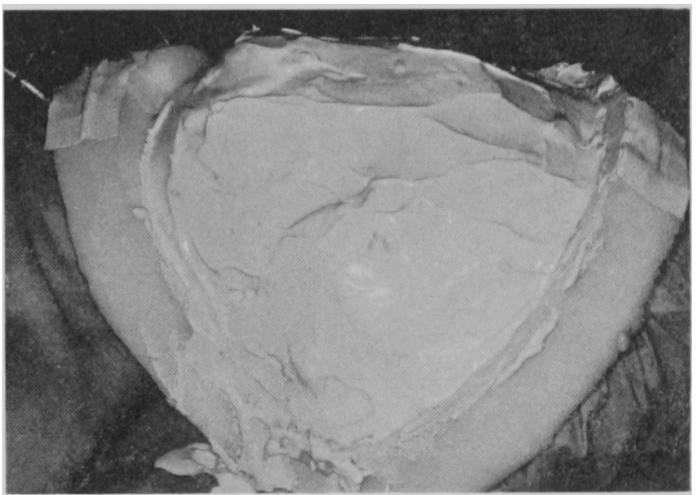

写真 2 衙中に扣ける颜面印象採得

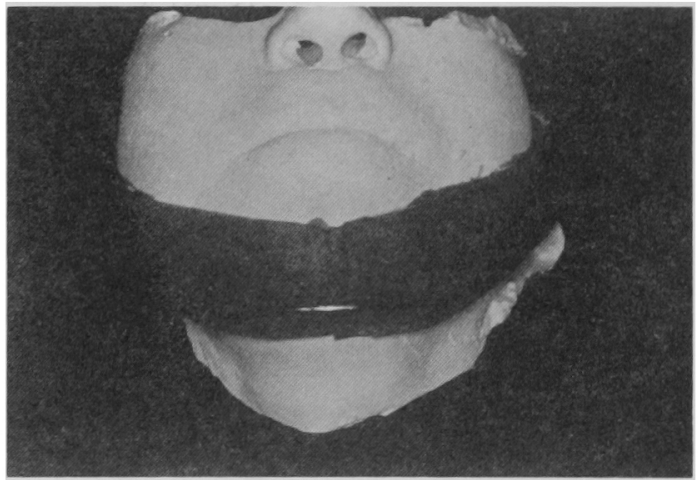

写真 3 顔面石育模型での作莱中

\section{1. 基本術式（術前準備）}

以下の基本術式は，術前に行らのを原則とするが，手 術時に顔面印象を採取し，手術中に並行して行って よい.

1) 患者の顔面印象を採得する，その際，有菌顎の患 者では咬頭嵌合位を，また義崡を装着している患者には

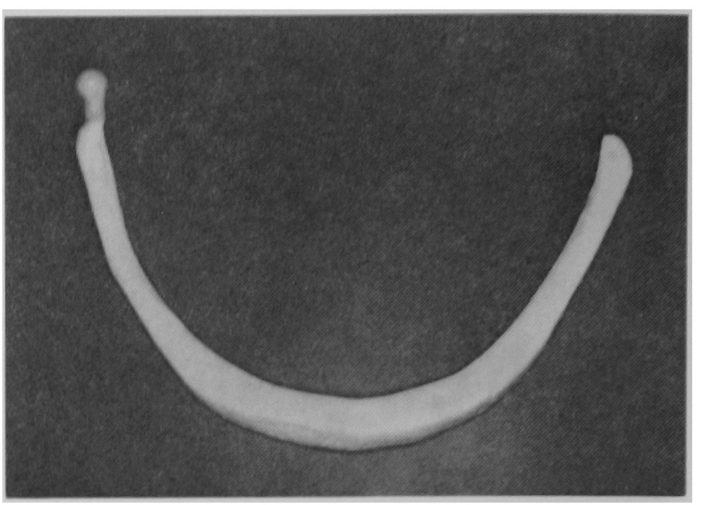

写查 4 筧成したレジン・ハーー

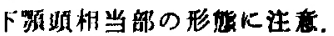

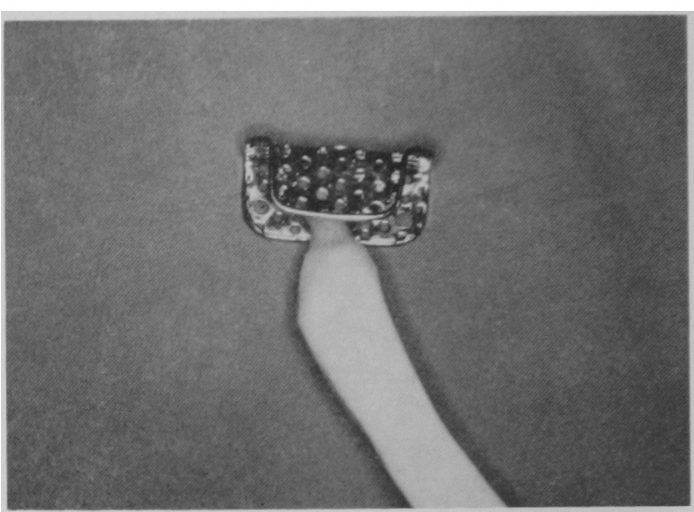

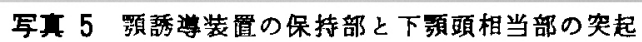
の位置的関係

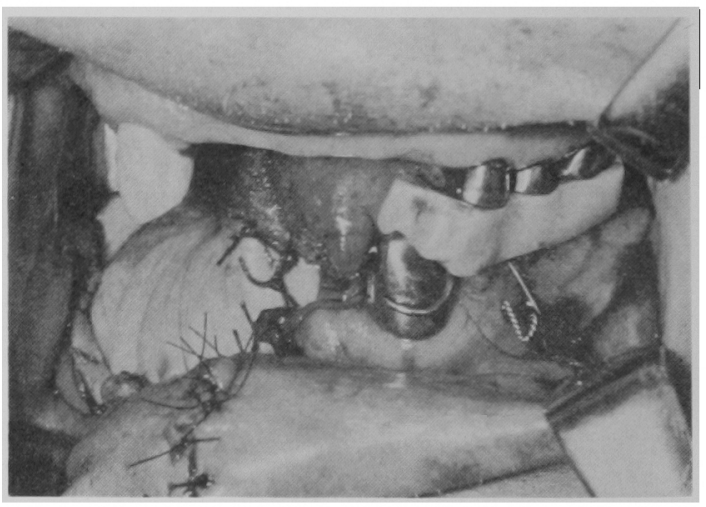

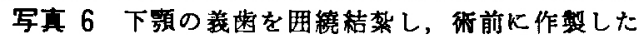
咬合床で上下影位圈関係を回復している

中心咬合位を取らす。印象採得する範围は，頭側では頓 骨、煩骨弓を含み，尾側では顎下部，オトガイ下部を含 み，背側では耳介を含むようにする，下筫骨を切除する 側の顔面に油性インクで類骨，煩骨弓，下筫頭を印記 し 


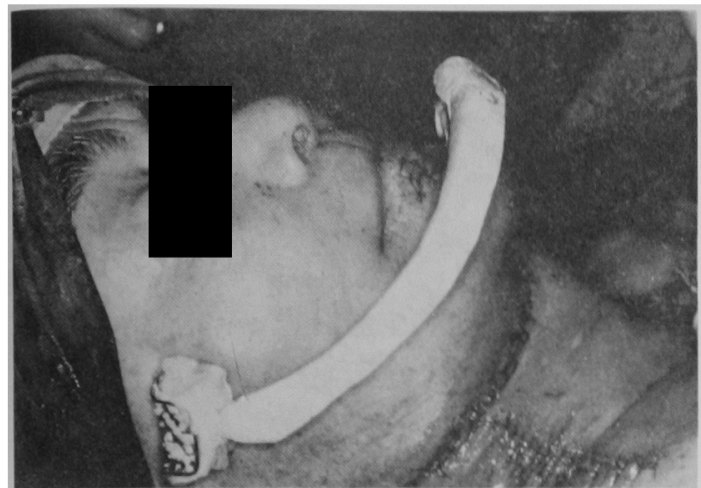

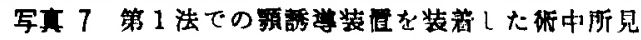

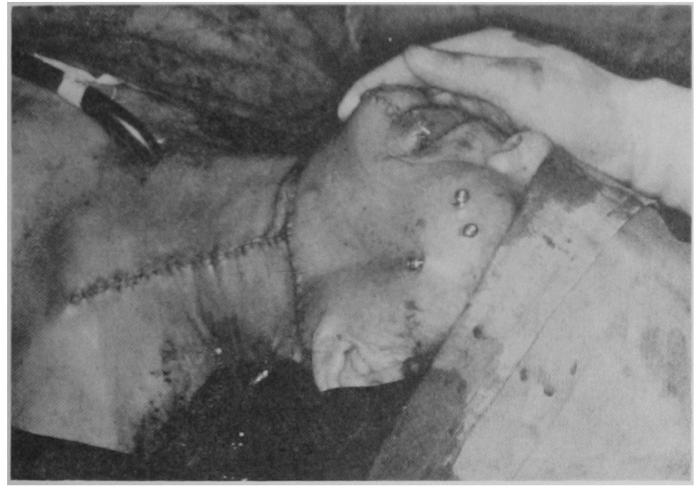

写真 8 第 2 法での頓骨部に骨釷を3本植立した術 中所見

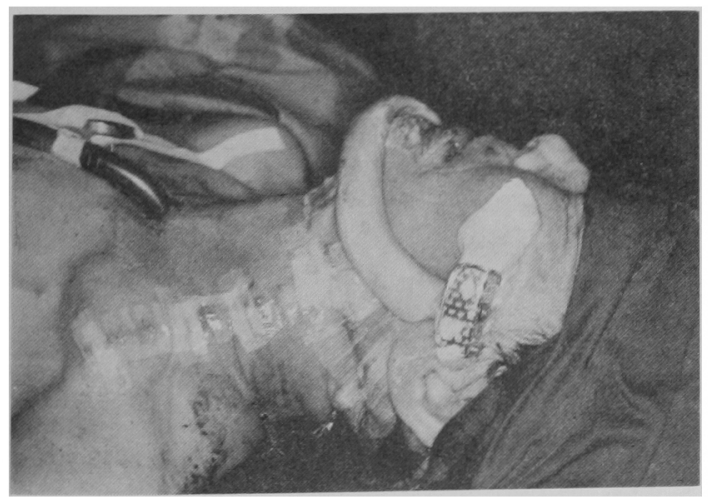

写真 9 第 2 法での顎誘導装置を装着した術中所見

てょくと，頓骨，頓骨弓，下影頭の位㯰が印象材を介し て石鲁模型上に写され，模型上での各々の位膡関係を確 認するさい有効である（写真 $1 ， 2$ ）.

2）顔面模型上で，切除する下頜を印記し，残存する 下顠す印記する。また1)で印記し、模型上に写された 頓骨，煩骨弓，下顎頭を明確にしておく。

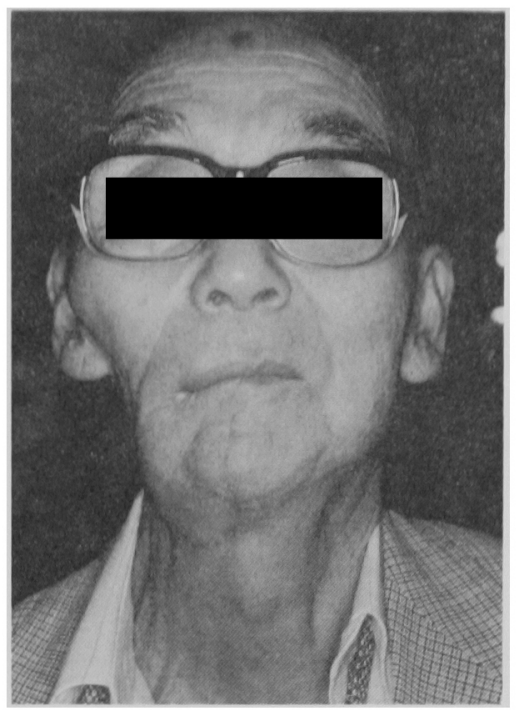

写高 10 症例 1 : 捗後 1 年の正貌

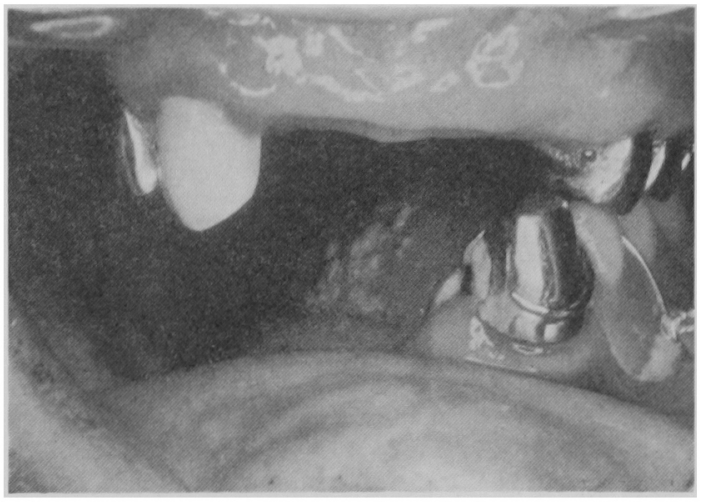

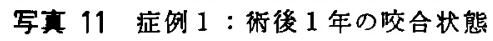
下顎の偏位を認めない。

3）2）で印記した下面骨相当部に;ニティリティ 一・ワックスを使い，5ないし $7 \mathrm{~mm}$ の厚さに盛る。こ の厚みがレシンン・ーと皮㨬の間のスペースに相当する (写直 3 ).

4) 即時重合レシンを用いて下䫑骨相当部にレジン・ バーを作製する、そのさい補強の意味でパラタル・ハー ないしはリンガル・ハーをレシンン内に入れたこともある が，現在では使用していない.

5）下顎頭に相当する突起を作製する. 外装型顎誘導 装圈内で回転, 滑走, 側方移動がスムースにできるよう に，表面は平滑，球型むしくは紡錐型に作製する，著者 は水道の蛇口の栓をシリコン印象材で印象採得し, その 内部に即時重合レシンを流し込んで作製している。それ を4)で作製したレシンン・シーに取り付ける。このさい 


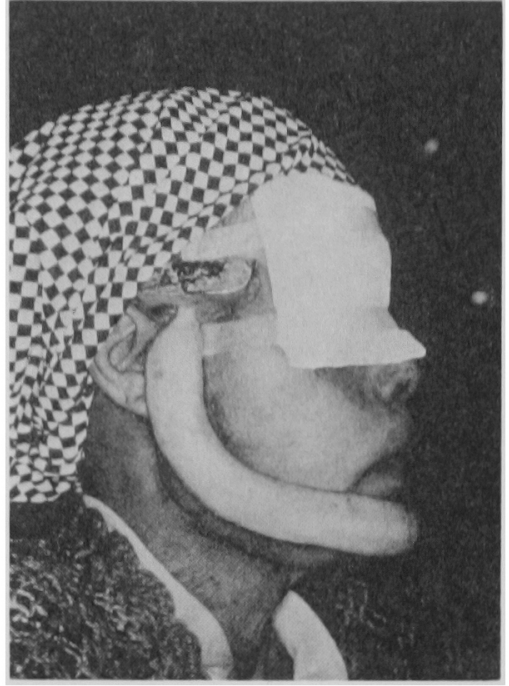

写卉 12 症侧 2 : 後後 1 か月の㑡㹸

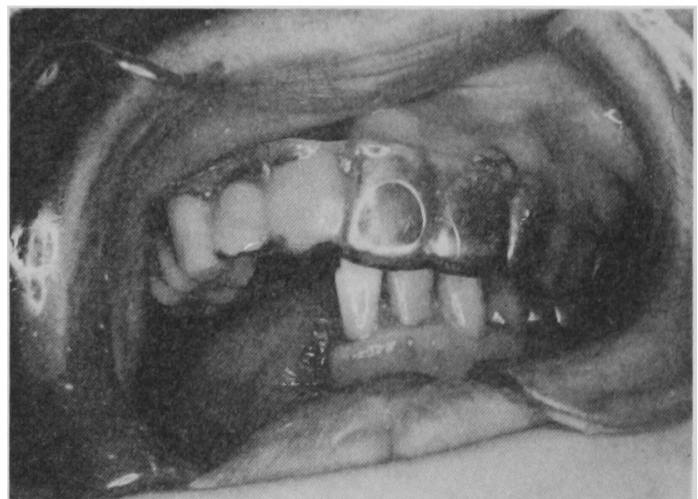

写真 13 症例 2 ：上額には整間的なレジン床が装着 されている。下顎の偏位を諗めない

顏面模型上に印記してある下顎頭の位直に突起か正確に 位置するよう注意する（写真 4 ）。

6）外装型顎誘導装固の保持部を作製する。手術中に 即時重合レシン (Cranioplastic(B) を使い外装型影誘樽 装置を作製するが，そのレジンを保持する必要がある。 歯科用印象トレー，とくに総山式臼歯用回枟トレーが有 奻である．煩骨弓に維持を求める第1法ではネジを通す 穴を 2 か所に開ける，頓骨に維持を求める第 2 法では必 要ない(写真 5 ).

2. 外装型領传荋装置の作製ならびにレジン・バーの 装着

以下は手術中の操作であるが，下䅡骨切除後に残存し た下顎骨を術前の位置に一時的に回復する必要がある。 そのさいには有歯影であれば，䫑間固定を行い，義歯装 着患者であれば，装着していた義歯を使い囲繞結㷊を行

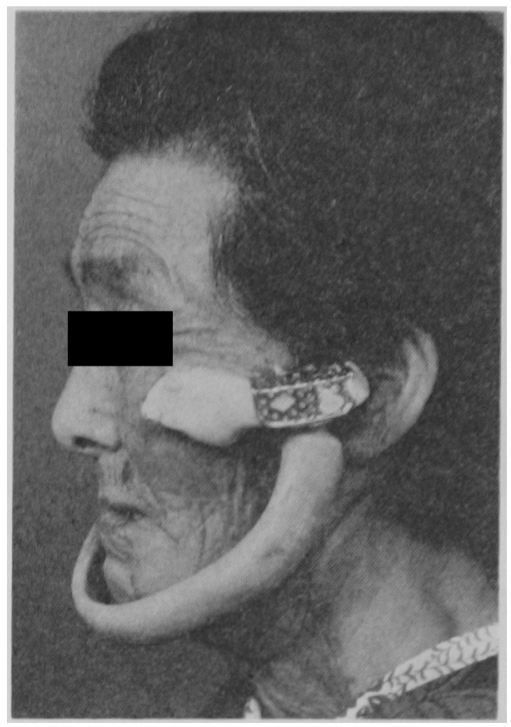

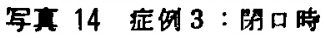

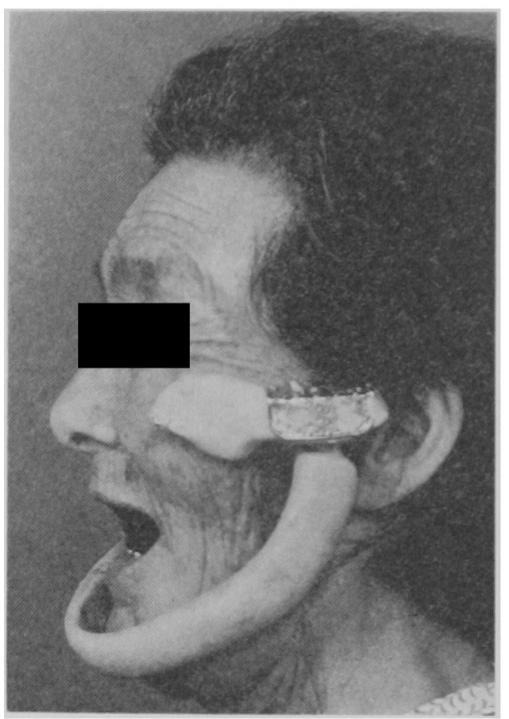

写真 15 症例 3 : 開口時

い義歯を固定後，上下顥の位㯰関係をまず回復して和く ことは，第 1 法，第 2 法共に同じである（写直 6).

7 ）健側下䫛骨に 4)，5）で作製したレジン・パー を骨邻で固定する，このさいレシンン・ーの下顎頭相当 部を，切除した下額頭の位置の皮虞上にくるようにする ことが重要である，骨釗は 2 ないし 3 か所に植立する.

8）外装型顎誘導装祜の作製

第1法：骨釘を6）で作製した穴を通して煩骨弓に植 立する。その後 Cranioplastic®をトレーに填入する。な おそれに先立らレジン・バーの下箱頭相当部に軟育すし 


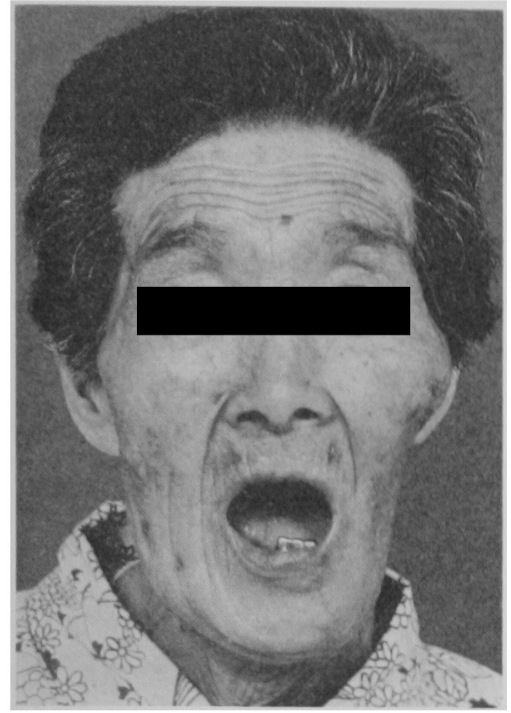

写衰 16 证例 3 : 頻誘導装置解除後の開 口時. 下影の偏位は泽度である

くはワセリンを塗り Cranioplastic®と接合しないよらに する. 次いで額間固定をはずし、レジン・ハーを保持し て開閉運動，側方運動等の影運動をCranioplastic®の重

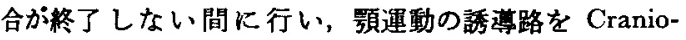
plastic®を使用した外装型影誘導装㯰に作製する（写真 7 ).

第 2 法：頓骨に 3 か所骨釗を植立する，そのさい 3 点 の各々の距離があまり近くならないよらにする.つい トレーをレシン・ハーの下頻頭相当部に被せるよらに膡 く、レシンン・゙ーの下影頭相当部に軟青るしくはワセリ ンを塗りCranioplastic®と接合しないようにすることは 同しであるが, Cranioplastic®を使い，頓骨に植立した 骨釷とトレーを連結させ，同時にトレー内にす填入す る，重合熱による皮凰の熱傷を防止するため，皮膚上に 軟育を塗布したがーゼを膡き，重合の完了するまで注水 する.なおその間に顎運動を行らことは第 1 法と同してて ある(写真 8,9$)$.

\section{症}

例

著者は第 1 法を1983年 3 月⿴日に行ったのが最初であ

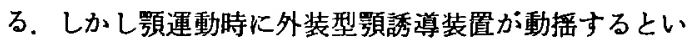
ら欠点がみられたため, 第 2 法を考案した。では第 1 法 の適応がまるでないかというと，下頻骨半側切除上上靧 切除が同時に必要な症例では第 2 法は適用できないため 第 1 法が適応となる．以下打のおのを適用した代表症例 を報告する。

症例 1 : 右下顎骨中心性癌で，舌根部への浸潤がみら
表 1 体外閌子の分煩

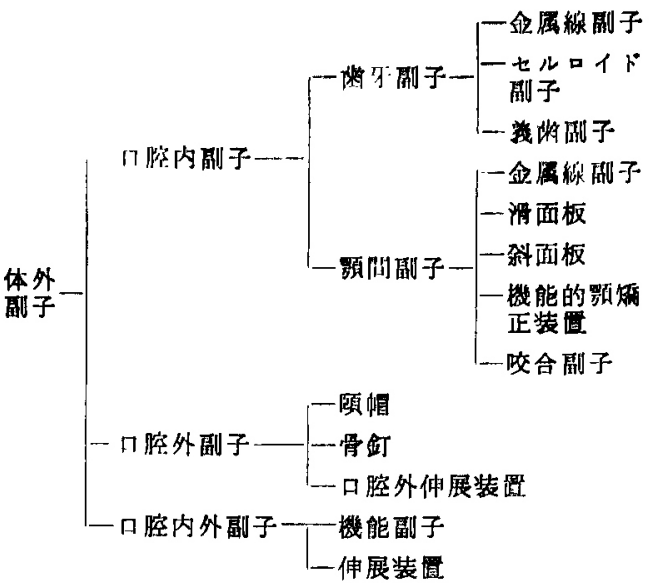

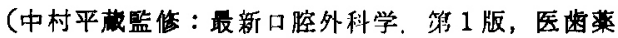
出版, 東京, 1971，199面)

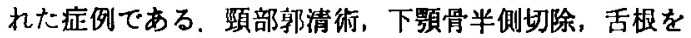
含も舌半側切除術を施行し，軟組織の久損には大胸筋皮 弁で再建を行ったが，切除簀囲が大きくなり，自家骨に よる即時再建を行うことは母床側の条件が悪いと判断し 第 1 法を適用した。 術後より開口は可能であり，また健

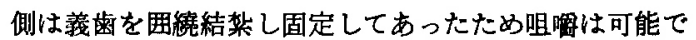
あった。しかし舌根部に切除が及んたため，憅下運動に 障害がみられた， 4 か月問装稙を装着したが，解除後 1 年6か月後の現在む下影の偏位は軽度であり，骨移植に よる下影骨再建を予定している（写真10，11）。

应例 2 : 右上顥癌の翼实下䫛隙を介した下影骨への浸 潤がみられた症例であり，耳年咽喉科医より下筼の処置 を俵頼された症例である。手術は下買骨半側切除，上䫑 切除，頭蓋度の郭清術がなされた。症例 1 と同様下顥骨 の即時再建の適応はないるのと判断した、第 2 法は適用 できないため第 1 法により買偏位防止を計った，有再影 であったため，術後早期より咀唃，絔下は可能であった (军南12, 13).

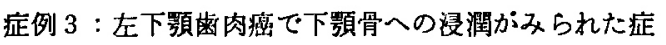

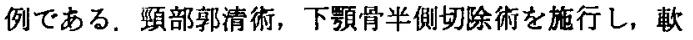
組䅧の欠損には大胸筋皮弁で再建を行った．しかし症例 1 と同様, 下影骨の即時再建の適応はないと判断し、第 2 法により顠偏位防止を計った。 2 か月間本装固を装着 したが解除後も下䫑の偏位は軽度であり，術後 6 か月の 現在，上下影に義藏を装着し経過観察中である（写卉 14 16).

\section{考察}

腫煌等で下矤骨の切除が施行されることは，口腔外科 臨床ては比較的多い，切除の筙囲は，疾患およびその進展 


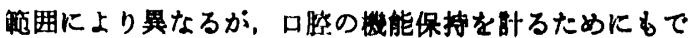
きれば即時再建が望主しい，しかし移植部の条件が思い ため即時再建は避けた方が良い均合むある。 Kazanjian

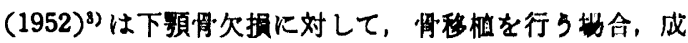
功に迸くためには，(1)健康な組樴に骨移杫を行らこと。 （2）称植部には十分な血行があること（3)移相骨と接合 する骨との間の接触が厸いこと（4)固定が強固である こと.の 4 点をあげている. 例示した 3 症例のこととく， 惩性茞病では術前に放射線照射が行われる场合もあり， また手行後に大きな板組織欠损をきたす场合も多く，下 額骨の即時再量には不利な条件が直なっている，实際，

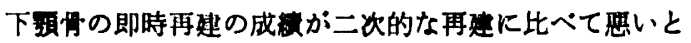

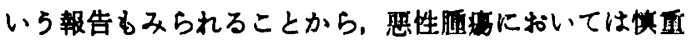
に対処する必要がある.

さて，二次的に再建を行ら埸合に注意すべき点は，残 存する下積骨の上䫑に対する位圈関保を下顶骨切除を行 5以前の位雵に正しく保持することである”。．そのため には下預骨切除時に上下影の位固関係を保持しておく方 が有利である. 有歯影の患者では残存する歯を利用し, 上下影の位圈関係を正確に保持することは可能である が, 無菌影者では種々の工夫が必要となる. 藤岡らはそ れらに利用する副子を体内副子と体外副子に分け記载し ているが（表 1)，体内副子を利用するさいKは前述し た Kazanjian のあげている原則を守る必要があると考 えられ，悪性腫湯の患者には遒用できない場合も多い。 このようなさいには体外副子が通応になる。

これらのなかで,下頻頭を含む下頻骨切除を行い,かつ 雪を利用できない場合に利用可能なるのとして，口腔内 副子の顥間副子では咬合副子，口腔外副子では碩帽，骨 釷が考えられる。しかし咬合副子ではその椎持のため, 囲繞結热もしくは顗帽の併用が必要であり，頋帽単独で は固定力に限界があると思われる. 残る骨釘を利用した 装置には種々のものがあるが，下影頭を含む下影骨切除 後の骨釘による固定では従来固定源を, 頭蓋, むしくは 上額骨, 頓骨飞求め, 固定期間中の額運動は不可能であ った. 額運動の制限による心理的影響の報告例もみら れ2), かつ症例 $1 ， 3$ のように皮弁により口腔の再建を 行った場合には，術直後よりの綿密な皮弁の観察のため 開口が可能な方が望ましい，著者の考察した方法は基本 的には骨釘を利用したものであるが，術後の䪽運動を可 能にするため切除された下䫑頭相当部の皮成の外側に外 装型影誘導装置を作製し，それを介して残存した下影骨 の位直偏位を防止しようとするすのである。最近 Marx ${ }^{6)}$ は同様の試みを報告しているが，それでは蝶板を利用し ているため, 蝶板運動のみしか可能ではなく，十分な咀 嚼はできないるのと思われる. 著者の方法では即時重合 レシシンを用い, その内部に, 回転, 滑走, 側方運動の運 動路を作るため，比較的自由な簤運動が可能となってい る. 本法の問題点は外装型䝷誘導装置の固定に難点があ
る点で，とくに第1法では十分な固定は得られなかっ た，第 2 法では此的良好な結果が得られたが，しかし それであ不十分であり，現在暊蓋骨を固定源にした方法 を哮中である。

固定期闪については症例む少なく現時点では断言でき

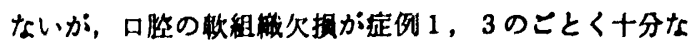

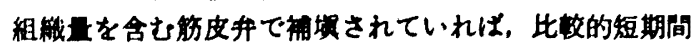
の固定で十分ではないかと推瀴している。ささらに最近。 下影頇を含まない损の症例で，一定期间，固定を施行

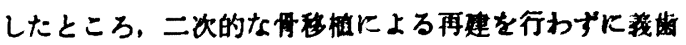

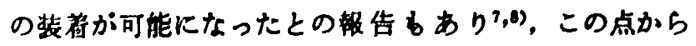
もどれたけけの期间固定を行ったらよいかについての铁討 は是非必要であると考える。

\section{結媓五}

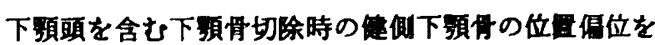
防止する目的で，従来のレジン・ハーの道応を払大し。 影運動が可能な外装型預唀導装置を考案し良好な結果を 得たのでその術式を報告した。 さらに䧗床例についても 報告した。利点としては

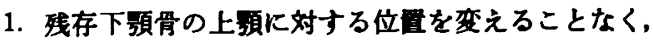

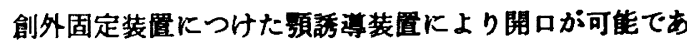
る.

2. 開口が可能なため，術後早期から食物の怿口摄取 が可能である.

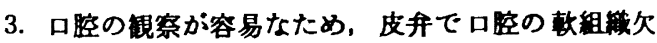
損部の即時再建を行った場合には術後の盽察および管理 が容易である.

さらに開口制限がないので心理的要影零は少ないので はないかと推測している.

穗を釉えるにあたりここ校圆いただきました筑波大学 臨床医学采，根本一男教授比深懒します。

本論交の一部は，第28回日本口腔外科学会视会 (1983 年 9 月29,30日，東京）においてビデォ発表した。

\section{引用文 薢}

1) Lawson, W., Loscalzo, L.J., et al.: Experience with immediate and delayed mandibular reconstruction. Laryngoscope 92: 5-10 1982.

2) Dubois, D.D., Pizer, M.E., et al.: Psychosexual dysfunction in patients with immobilized jaws. Oral Surg 46: 506-510 1978.

3) Kazanjian, V.H.: Bone transplanting of the mandible. Am J Surg 83: 633-639 1952.

4) Converse, J.M. : Reconstructive plastic surgery. 2 nd Ed, W.B. Saunders Co, Philadelphia, 1977, p 1474. 


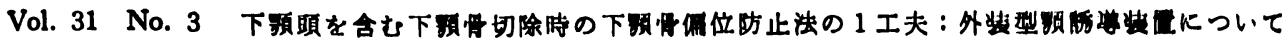

5) 中村平花監攸：最新口腔外科学。第 1 版，医曲 菜出版, 東京, 1971，199頁.

6) Marx, R.E.: A modified external pin appliance for resections that include the mandibular condyle. J Oral Maxillofac Surg 42: 203-204 1984.

7) Leeb, D.C., Friedlander, A.H., et al.: Man- dible stabilization between ablative and reconstructive surgery. Head Neck Surg 2: 67-70 1979.

8) Bergman, S.A., Elias, E.G., et al.: Maintenance of function and esthetics after partial mandibulectomy without bone grafting. J Oral Surg 39: 421-425 1981. 